\title{
Uncertainty and Fiscal Policy in an Asymmetric Monetary Union
}

\author{
CARSTEN HEFEKER \\ BLANDINE ZIMMER
}

CESIFO WORKING PAPER NO. 2389

CATEGORY 6: MONETARY POLICY AND INTERnATIONAL FINANCE

SEPTEMBER 2008

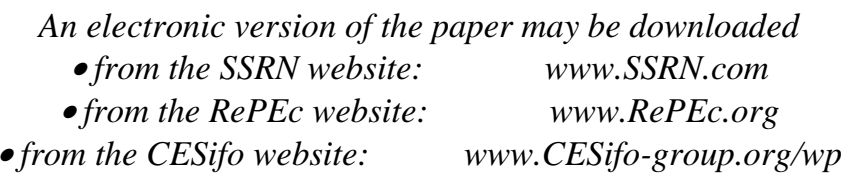




\title{
Uncertainty and Fiscal Policy in an Asymmetric Monetary Union
}

\begin{abstract}
The paper examines the monetary-fiscal interactions in a monetary union model with uncertainty due to imperfect central bank transparency. We first show that monetary uncertainty disciplines fiscal policymakers and thereby reduces taxes, average inflation and output distortions. However, as more members enter the monetary union, the fiscal disciplining effect of uncertainty is mitigated. As a consequence, monetary union enlargement may lead to a more aggressive fiscal stance in some member countries, depending on their relative economic and political weights, on their government's spending target, and on the change in the degree of uncertainty that they experience with the enlargement.
\end{abstract}

JEL Code: E58, E63, F36.

Keywords: monetary union, fiscal policy, transparency of monetary policy, asymmetries.

\author{
Carsten Hefeker \\ University of Siegen \\ Hoelderlinstrasse 3 \\ 57068 Siegen \\ Germany \\ carsten.hefeker@uni-siegen.de
}

\author{
Blandine Zimmer \\ University Louis Pasteur \\ 61 avenue de la Forêt Noire \\ 67085 Strasbourg Cedex \\ France \\ zimmer@cournot.u-strasbg.fr
}

July 2008 


\section{Introduction}

The European central bank (ECB) is usually considered to be less transparent than other major central banks in advanced economies such as the Federal Reserve in the US or the Bank of England (Blinder et al. 2001; Dincer and Eichengreen 2007). The ECB is widely criticized for this, and most of the literature argues that more transparency is better than less because it allows the private sector to make better informed decisions. In particular, it is argued that preferences and goals should be communicated clearly (Blinder 1998).

More recently, however, there are also approaches in the literature which argue that less than maximum transparency is desirable. In particular, it is argued that creative ambiguity (Cukierman and Meltzer 1986) can discipline the private sector, such as wage setters, and induce governments to pursue more employment friendly policies. This paper contributes to this debate and considers the influence of central bank transparency on fiscal policies in an asymmetric monetary union. ${ }^{1}$

In developing our arguments, we complement earlier studies in two different strands of literature. First and most obviously, our paper is related to the huge literature on the influence of monetary policy uncertainty (Brainard 1967; Söderström 2002). Most of those papers show that monetary policy becomes less aggressive if there is uncertainty about its impact, such as is the case with uncertainty about the transmission of monetary policy (Gros and Hefeker 2002; Benigno 2004). This literature has more recently taken a different approach by introducing the response of domestic agents to uncertainty about the central bank's reaction function. ${ }^{2}$ Sorensen (1991), Grüner (2002) and Grüner et al. (2005), for instance, demonstrate that uncertainty on monetary policy may discipline wage setters.

A player that has received relatively little attention here is the fiscal authority. Only a few contributions have so far combined the issue of central bank transparency with fiscal policymaking. Hughes Hallett and Viegi (2003) model a monetary-fiscal policy game to investigate the effects of transparency, depending on whether it corresponds to political transparency (where the central bank's preferences are clearly defined) or economic transparency (where the central bank's targets are made clear). Ciccarone et al. (2007) develop a model of a unionised economy with supply-side fiscal policy and consider the influence of central bank transparency on strategic wage setting. However, none of these papers has explicitly examined how fiscal authorities react to transparency. Our contribution aims to fill this void and to show how this reaction is transformed in a monetary union.

\footnotetext{
${ }^{1}$ The concept of transparency used here refers to "preference uncertainty". For a recent discussion, see Hughes Hallett and Libich (2006) and Geraats (2002).

${ }^{2}$ This literature is however much too broad to be completely referenced here. See, for instance, Eijffinger and Hoeberichts (2000), Winkler (2000) Geraats (2002) and Eijffinger and van der Cruijsen (2007) for surveys.
} 
In this way, our paper can also be linked to the broad discussion about monetary and fiscal interactions in a monetary union. This literature however is too broad and diverse to be adequately referenced here, but includes important contributions as for instance, Beetsma and Bovenberg (1998, 1999), Beetsma and Uhlig (1999), Dixit and Lambertini (2001, 2003) and Uhlig (2003) von Hagen and Wyplosz (2008). In this paper, we make use of the framework developed by Beetsma and Bovenberg (1998) to offer some insights as to how the enlargement of a monetary union may affect tax decisions and economic outcomes in the member countries. Beetsma and Bovenberg (1998) showed that the formation or the enlargement of a monetary union can discipline national fiscal policymakers and thereby reduce taxes, inflation and the public spending bias. ${ }^{3}$ This result is due to the fact that the strategic position of each individual fiscal player vis-à-vis the common central bank is weakened in a monetary union.

Our paper develops Beetsma and Bovenberg (1998)'s analysis in two further ways. First, it assumes that the reaction of monetary policy to taxation is to some degree uncertain. The issue of uncertainty is particularly relevant when examining the repercussions of the enlargement of a monetary union. As pointed out by Goldberg and Klein (2005) or Hefeker (2008) such a change in the monetary regime is likely to create some additional uncertainty in the participating countries. The decisions of a larger central bank reflect all kinds of preferences and interactions among the different member countries and are thereby less predictable.

Second, our paper also considers cross-country asymmetries among the old and new members. Indeed, the enlargement will also imply that the degree of heterogeneity among member countries increases. This may have an effect on the common monetary policy and it may feedback on the optimal fiscal policies in the member states. Three possible asymmetries are focused upon: 1) differences in the political and economic weights of the countries; 2) differences in their degree of monetary uncertainty; 3) differences in the governments' spending targets. These asymmetries could reflect the extension of EMU to middle and eastern European countries. ${ }^{4}$ In particular, the governments' spending targets differ widely among old and new member states in the EU, implying different tax burdens on the population and thus on the output levels in Europe. Consequently, by integrating monetary uncertainty and cross-country asymmetries, we qualify Beetsma and Bovenberg (1998)'s result and demonstrate that the tax-decreasing effect of the monetary union (enlargement) does not necessarily hold any longer.

Our principal results can be summarised as follows. We first show that monetary uncertainty disciplines fiscal policymakers and thereby reduces taxes, average inflation and output distortions. Thus, maximum transpar-

\footnotetext{
${ }^{3}$ The creation and the extension of a MU affect economic outcomes through similar mechanisms.

${ }^{4}$ Depending on the type of asymmetry, a more relevant example could also be a monetary union between continental Europe, such as Germany and France, and the UK.
} 
ency need not be optimal from this point of view. However, as more members enter the monetary union, the fiscal disciplining effect of uncertainty is mitigated. As a consequence, monetary union enlargement may lead to a more aggressive fiscal stance in some member countries, depending on their relative economic and political weights, on the governments' spending target, and on the change in the degree of uncertainty that the particular country experiences with the enlargement. Our conclusion is that deliberate uncertainty can help to reduce distortions arising from fiscal policy so that lower central bank transparency could be an optimal response to monetary union enlargement. This solution, however, should be used cautiously as it could prove to be counterproductive for countries characterized by a high public spending target.

The paper is organized as follows. The next section analyzes the effects on uncertainty on fiscal decisions in a closed economy. Section 3 extends this analysis to a monetary union and derives the effects of the its enlargement on macroeconomic outcomes. Two cases are considered: The benchmark case of a symmetric monetary union and the more complex case of a monetary union with heterogenous countries. Section 4 concludes.

\section{Policy choices in the closed economy}

This section presents a model in line with Beetsma and Bovenberg (1998) extended to allow for imperfect political transparency of the central bank as in Demertzis and Hughes Hallett (2007). ${ }^{5}$

\section{$2.1 \quad$ The model}

We begin by considering a closed economy (indexed by $i$ ) consisting of three players: the central bank, the government and the private sector. The timing of the game is as follows: (i) the private sector sets its expectations, (ii) the government sets the rate of taxation, (iii) the central bank determines inflation, and (iv) output is realized.

Since in practice monetary policy can be adjusted more quickly than the fiscal decisions, we assume that the government is a Stackelberg leader visà-vis the central bank. Thus, when setting taxes, the government takes the expected reaction of the central bank into account. The private sector, however, is not coordinated and thus not able to internalize the policymakers' reaction. This reflects the fact that the atomistic private sector takes policy

\footnotetext{
${ }^{5}$ Demertzis and Hughes Hallett (2007) distinguish imperfect political transparency from imperfect economic transparency. The former relates to the misunderstandings about the central bank's preference parameters whereas the latter is due to the misperceptions about its targets. A similar distinction is made in Hughes Hallett and Viegi (2003) and Geraats (2002).
} 
decisions as given and adjusts its behaviour only gradually because, for instance, wage contracts are fixed for a certain time period. ${ }^{6}$ We therefore assume that the private sector plays Nash against the central bank and the fiscal authority. The model is solved by backward induction.

Output $x_{i}$ is increasing in surprise inflation $\pi_{i}-\pi_{i}^{e}$ and decreasing in the tax rate $\tau_{i}$.

$$
x_{i}=\pi_{i}-\pi_{i}^{e}-\tau_{i}
$$

The government aims to minimise a loss function defined over inflation, output and public expenditure deviations from a given target, $g_{i}-\tilde{g}_{i}$

$$
L_{G, i}=\alpha \pi_{i}^{2}+x_{i}^{2}+\beta\left(g_{i}-\tilde{g}_{i}\right)^{2}
$$

where $\alpha$ and $\beta$ respectively measure the government's relative dislike of inflation and deviations of public expenditure from a target level. ${ }^{7}$ The first two aims are standard in the literature, while the third aim should reflect the optimal size of the public sector in the economy. This could either be due to different societal preferences over the size of the welfare state or due to political economic considerations of the government that aims to boost public investment to increase reelection chances (Drazen and Brender 2005).

In setting the public expenditures level, the government faces a balanced budget constraint:

$$
g_{i}=\tau_{i}
$$

We, hence, do not focus on debts and deficits, as in Beetsma and Bovenberg $(1997,1999)$ for instance, and we also rule out that seignoriage contributes to financing the budget. Our model is thus in spirit of a long-run model with a balanced budget requirement.

In specifying the central bank's loss function, we draw on Ciccarone et al. (2007):

$$
L_{C B, i}=(I-\epsilon) \pi_{i}^{2}+(1+\epsilon) x_{i}^{2}
$$

where $I$ measures the central bank's degree of conservatism; $\epsilon$ is a random variable with $\epsilon \in[-1, I], E(\epsilon)=0$ and $E\left(\epsilon^{2}\right)=\sigma_{\epsilon}^{2}$. The issue of monetary uncertainty arises as the central bank is not fully transparent in terms of its preferences. Although the government and the private sector are on average able to predict these preferences, there is some degree of uncertainty. The implications of this uncertainty for equilibrium can be determined by considering the consequences of the variance of $\sigma_{\epsilon}^{2}$, which we interpret as the degree of monetary uncertainty. ${ }^{8}$ Different central banks could thus be

\footnotetext{
${ }^{6}$ Cukierman and Lippi (1999) show that an atomistic private sector does not internalize the central bank's reaction to its behavior.

${ }^{7}$ Note that the parameters $\alpha$ and $\beta$ are not indexed by $i$. Thus, we assume that the governments' relative dislike of inflation and public spending deviations are identical across countries. Allowing different spending targets suffices to derive asymmetric policy choices.

${ }^{8}$ Note that $\sigma_{\epsilon}^{2} \in[0, I]$ as the random variable $\epsilon$ is defined in a compact set and has an expected value equal to zero. See the Appendix of Ciccarone et al. (2007) for further details.
} 
distinguished by how high they score on a transparency index (for a recent study, see Dincer and Eichengreen (2007)).

The solution of the central bank's problem is derived from Eqs. (1) and (4) and is given as:

$$
\pi_{i}=\frac{1+\epsilon}{1+I}\left(\pi_{i}^{e}+\tau_{i}\right)
$$

Inflation is increasing in expected inflation and taxation because the central bank aims to compensate their negative effect on output. It is also increasing in the stochastic weight for output $\epsilon$ but decreasing in the central bank's aversion to inflation.

The government determines its fiscal decisions by minimising $E\left(L_{G, i}\right)$ subject to the budget constraint (3) and the central bank's reaction function (5). This yields the following tax rate :

$$
\tau_{i}=\frac{\tilde{g}_{i} I(1+I) \beta}{\alpha\left(1+\sigma_{\epsilon}^{2}\right)+\sigma_{\epsilon}^{2}+I^{2}+I(1+I) \beta}
$$

Clearly, taxation is increasing in the spending target and falling in preference uncertainty. The latter leads to lower taxation because the government cannot rely on the central bank's reaction to distortionary taxes and thus acts more cautiously. The influence of central bank inflation aversion on taxes is ambiguous but likely to be positive if uncertainty is large. ${ }^{9}$

Finally, the equilibrium values for inflation, output and public expenditure deviations are respectively given by:

$$
\begin{aligned}
\pi_{i} & =\frac{\tilde{g}_{i}(1+I) \beta}{\alpha\left(1+\sigma_{\epsilon}^{2}\right)+\sigma_{\epsilon}^{2}+I^{2}+I(1+I) \beta}(1+\epsilon) \\
x_{i} & =\frac{-\tilde{g}_{i}(1+I) \beta}{\alpha\left(1+\sigma_{\epsilon}^{2}\right)+\sigma_{\epsilon}^{2}+I^{2}+I(1+I) \beta}(I-\epsilon) \\
g_{i}-\tilde{g}_{i} & =\frac{-\tilde{g}_{i}\left[\alpha\left(1+\sigma_{\epsilon}^{2}\right)+\sigma_{\epsilon}^{2}+I^{2}\right]}{\alpha\left(1+\sigma_{\epsilon}^{2}\right)+\sigma_{\epsilon}^{2}+I^{2}+I(1+I) \beta}
\end{aligned}
$$

As can be seen from Eqs. (6) through (9), the higher is the targeted level of public expenditure $\tilde{g}_{i}$, the higher is the need to use distortionary taxation and the further away are inflation, output and public expenditures from their respective targets.

\subsection{The effects of monetary uncertainty}

This section examines the effects of uncertainty about central bank preferences on the average level and the variability of economic outcomes. These effects are summarised in the following result.

\footnotetext{
${ }^{9}$ This follows from $\partial \tau_{i} / \partial I=(1+2 I)\left[a\left(1+\sigma_{\epsilon}^{2}\right)+\sigma_{\epsilon}^{2}\right]-I^{2}$.
} 
Result 1. Monetary uncertainty reduces taxes, average inflation and output distortions but increases deviations of public expenditures from their target level.

Proof. Taxes and average inflation decline in $\sigma_{\epsilon}^{2}$ as can be seen respectively from Eqs. (6) and (7) while, according to (8), average output increases with $\sigma_{\epsilon}^{2}$.

Concerning the impact of uncertainty on public expenditure deviations, we obtain:

$$
\frac{\partial\left(g_{i}-\tilde{g}_{i}\right)}{\partial \sigma_{\epsilon}^{2}}=\frac{-\tilde{g}_{i} I(1+I)(1+\alpha) \beta}{\left\{\alpha\left(1+\sigma_{\epsilon}^{2}\right)+\sigma_{\epsilon}^{2}+I^{2}+I(1+I) \beta\right\}^{2}}<0
$$

Result 1 can be explained by Brainard's (1967) principle of policy caution. Monetary uncertainty amplifies the (perceived) marginal costs associated with higher taxes and thereby induces the government to adopt a less aggressive fiscal policy. This in turn brings about lower output distortions and lower average inflation. However, as taxes decrease, so does the public expenditure level, thus bringing the government further away from its desired level of spending.

Result 2. Inflation and output variability decrease with monetary uncertainty if the latter is sufficiently high.

Proof. Using $\sigma_{\pi_{i}}^{2}=E\left[\pi_{i}-E\left(\pi_{i}\right)\right]^{2}$ and $\sigma_{x_{i}}^{2}=E\left[x_{i}-E\left(x_{i}\right)\right]^{2}$, we get $\sigma_{\pi_{i}}^{2}=\sigma_{x_{i}}^{2}=\tau_{i}^{2} \cdot \sigma_{\epsilon}^{2} / I^{2}$. Differentiating $\sigma_{\pi_{i}}^{2}$ and $\sigma_{x_{i}}^{2}$ with respect to $\sigma_{\epsilon}^{2}$ yields:

$$
\frac{\partial \sigma_{\pi_{i}}^{2}}{\partial \sigma_{\epsilon}^{2}}=\frac{\partial \sigma_{x_{i}}^{2}}{\partial \sigma_{\epsilon}^{2}}=\frac{\tilde{g}_{i}{ }^{2}(1+I)^{2} \beta^{2}\left[\alpha-\sigma_{\epsilon}^{2}(1+\alpha)+I^{2}+I(1+I) \beta\right]}{\left\{\alpha\left(1+\sigma_{\epsilon}^{2}\right)+\sigma_{\epsilon}^{2}+I^{2}+I(1+I) \beta\right\}^{2}}
$$

This derivative is negative if the following condition is fulfilled:

$$
\sigma_{\epsilon}^{2}>\frac{\alpha+I[I+\beta(1+I)]}{1+\alpha}
$$

Hence, more uncertainty about central bank preferences does not necessarily translate into more inflation variability. This result is in the line with the findings of Grüner (2002) and Grüner et al. (2005). ${ }^{10}$ Indeed, less transparency triggers two opposing effects on macroeconomic volatility. On one hand, it directly increases inflation and output variability as it generates more uncertainty in the economy. On the other hand, as shown in the previous result, opacity leads to greater fiscal discipline and in this way contributes to reduced inflation and output variability. We refer to this latter effect as the 'disciplining effect'. Its importance depends, in particular, on the degree

\footnotetext{
${ }^{10}$ In fact, Grüner (2002) and Grüner et al. (2005) obtain this result in a framework with strategic interactions between the central bank and non-atomistic wage setters.
} 
of monetary uncertainty $\sigma_{\epsilon}^{2}$. Therefore, when $\sigma_{\epsilon}^{2}$ is high, this 'disciplining effect' may dominate the other effect so that the overall impact of central bank opacity on macroeconomic variability eventually becomes negative.

Moreover, from rewriting condition (10) as $f(I, \beta) \equiv \frac{\alpha+I[I+\beta(1+I)]}{1+\alpha}<\sigma_{\epsilon}^{2}$, we find $\frac{\partial f}{\partial I}>0$. Hence, the lower is the central bank's aversion to inflation $I$, the more uncertainty is likely to reduce macroeconomic variability. This happens since a lower $I$ amplifies monetary policy uncertainty and thereby strengthens the 'disciplining effect' on fiscal policy.

Besides, we also observe that: $\frac{\partial f}{\partial \beta}>0$. Whenever the government is less concerned about the public expenditure deviations, it is more prone to reduce taxes in response to greater uncertainty. This means that a lower $\beta$ is associated with a stronger 'disciplining effect' and therefore with greater probability that monetary uncertainty reduces inflation and output variability.

\section{Policy choices in the larger monetary union}

Having studied the interactions between monetary uncertainty and fiscal policy in a single economy, we now shift our attention to these interactions in a monetary union (MU) composed of two countries. We represent the current members of the MU by country 1 and the new entering members by country 2. We allow for cross-country differences in the targeted level of public expenditures. More precisely, we assume that the government in country 2 targets a higher public expenditure level than the government in country 1, so that: $\widetilde{g}_{2}>\widetilde{g}_{1}$. This could reflect a larger need for public investment, a preference for a larger welfare state, or simply the government's interest for higher expenditures for political economic reasons, such as increasing reelection chances.

With the MU extension (superscript $U$ ), the monetary policy is now centralised in the hands of a larger central bank (CCB) which sets the common inflation rate $\pi^{U}$ prevailing in both countries. ${ }^{11}$ We assume that the CCB's policy results from the interaction of both countries' monetary decisionmakers, so that the relative weights on inflation and output of the common central bank is a weighted average of national monetary authorities' preferences. The common central bank is assumed to target common inflation and a weighted average of output fluctuations. Its loss function is thus given by:

$$
L_{C C B}=\left(I-\epsilon^{U}\right)\left(\pi^{U}\right)^{2}+\left(1+\epsilon^{U}\right)\left(s_{1} x_{1}+s_{2} x_{2}\right)^{2}
$$

where $s_{1}+s_{2}=1, s_{i}(\forall i=1,2)$ measuring the member countries' relative economic weight; $\epsilon^{U}$ is a random variable with $\epsilon^{U} \in[-1, I], E\left(\epsilon^{U}\right)=0$ and $E\left(\epsilon^{U}\right)^{2}=\sigma_{\epsilon^{U}}^{2}$.

\footnotetext{
${ }^{11}$ We assume that the goods market of both countries are perfectly integrated. Therefore enlargement implies a common rate of inflation in both countries.
} 
MU extension means that new members are added to the union whose preferences are uncertain as well. As a consequence, even if on average new members have similar preferences to older members $\left(I_{2}=I_{1}=I\right)$, the uncertainty affecting their preferences can differ. Hence, we assume that the degree of uncertainty in the enlarged monetary union corresponds to a weighted average of the uncertainty in the individual member countries. It is defined by: $\sigma_{\epsilon^{U}}^{2} \equiv E\left(\epsilon^{U}\right)^{2}=z_{1} \sigma_{1}^{2}+z_{2} \sigma_{2}^{2}$, where $\sigma_{i}^{2}$ measures the preference uncertainty in country $i(\forall i=1,2)$ and $z_{i}$ its relative political weight $\left(z_{1}+z_{2}=1\right) .{ }^{12}$

In minimising Eq. (11), we have:

$$
\pi^{U}=\frac{1+\epsilon^{U}}{1+I}\left(\pi^{U, e}+\bar{\tau}\right)
$$

where $\bar{\tau}=s_{1} \tau_{1}+s_{2} \tau_{2}$ is the average tax rate in the extended union.

The government in country $i(i=1,2)$ chooses the tax rate to minimise its expected losses $E\left(L_{G, i}\right)$ (with $L_{G, i}$ defined in Eq.(2)) subject to (3) and (12), taking the other government's fiscal decision as given. The tax rate set by the government in country $i$ can thus be written:

$$
\tau_{i}^{U}=\frac{(1+I) \beta\left\{\tilde{g}_{i} \theta_{j}-\tilde{g}_{j} s_{i} s_{j}\left[\alpha\left(1+\sigma_{\epsilon^{U}}^{2}\right)+\sigma_{\epsilon^{U}}^{2}\right]\right\}}{\phi_{i} \theta_{j}+s_{i}^{2} \phi_{j}\left[\alpha\left(1+\sigma_{\epsilon^{U}}^{2}\right)+\sigma_{\epsilon^{U}}^{2}\right]}
$$

where index $j$ refers to country $i$ 's new partner in the MU;

$\phi_{i}=(1+I)(1+\beta)-s_{i}>0, \phi_{j}=(1+I)(1+\beta)-s_{j}>0$ and $\theta_{j}=$ $\left[\alpha\left(1+\sigma_{\epsilon^{U}}^{2}\right)+\sigma_{\epsilon^{U}}^{2}\right] s_{j}^{2}+I \phi_{j}>0$.

We see that tax rates are increasing in the domestic spending target but falling in that of the other country so that tax rates are strategic substitutes between countries. This is because higher taxes abroad increase common inflation, which forces the domestic government to lower domestic taxation in order to lower inflationary pressure on the common central bank. The implications of fiscal-monetary interactions in a MU with uncertainty are not obvious. We therefore have to start from the simple benchmark case where all countries have identical parameters. We then proceed to the more complex case of asymmetric countries.

\subsection{The symmetric case}

We first consider the simple case of symmetric countries, that is the case where both countries are identical in their public spending target, in their economic and political weight and in their degree of monetary uncertainty. In technical terms, we can write: $\tilde{g}_{1}=\tilde{g}_{2}=\tilde{g}, s_{1}=s_{2}=1 / 2, z_{1}=z_{2}=1 / 2$ and $\sigma_{1}^{2}=\sigma_{2}^{2}=\sigma_{\epsilon^{U}}^{2}$. This latter equality implies that the member countries do not experience any additional monetary uncertainty with the MU enlargement.

\footnotetext{
${ }^{12}$ The random variables $\epsilon_{1}$ and $\epsilon_{2}$, characterized by $E\left(\epsilon_{1}\right)=E\left(\epsilon_{2}\right)=0$ and $E\left(\epsilon_{1}\right)^{2}=\sigma_{1}^{2}$ and $E\left(\epsilon_{2}\right)^{2}=\sigma_{2}^{2}$, are assumed to be independently distributed.
} 
Substituting these parameter values into (13) yields the equilibrium tax rate in the symmetric case $\left(\tau_{1}=\tau_{2}=\tau\right)$ :

$$
\tau^{U}=\frac{2 \tilde{g} I(1+I) \beta}{\alpha\left(1+\sigma_{\epsilon^{U}}^{2}\right)+\sigma_{\epsilon^{U}}^{2}+I[2(1+I)(1+\beta)-1]}
$$

With this expression, we can show how the impact of uncertainty on tax decisions is modified by the MU enlargement. By comparing equations (6) and (14), we obtain the following result.

Result 3. The disciplining effect of uncertainty on taxes may be weakened in the enlarged $M U$.

Proof. Differentiating the equilibrium tax rates observed in the closed economy (Eq. (6)) and in the extended MU (Eq. (14)) with respect to $\sigma_{\epsilon}^{2}$ and $\sigma_{\epsilon^{U}}^{2}$ respectively, gives:

$$
\begin{aligned}
\frac{\partial \tau_{i}}{\partial \sigma_{\epsilon}^{2}} & =\frac{-\tilde{g} I(1+I) \beta(1+\alpha)}{\left[\alpha\left(1+\sigma_{\epsilon}^{2}\right)+\sigma_{\epsilon}^{2}+I^{2}+I(1+I) \beta\right]^{2}}<0 \\
\frac{\partial \tau^{U}}{\partial \sigma_{\epsilon^{U}}^{2}} & =\frac{-2 \tilde{g} I(1+I) \beta(1+\alpha)}{\left\{\alpha\left(1+\sigma_{\epsilon^{U}}^{2}\right)+\sigma_{\epsilon^{U}}^{2}+I[2(1+I)(1+\beta)-1]\right\}^{2}}<0
\end{aligned}
$$

For an initial degree of uncertainty, $\bar{\sigma}_{\epsilon}^{2}$, we find that

$$
\begin{gathered}
\frac{\partial \tau_{i}}{\partial \sigma_{\epsilon}^{2}}\left(\sigma_{\epsilon}^{2}=\bar{\sigma}_{\epsilon}^{2}\right)<\frac{\partial \tau^{U}}{\partial \sigma_{\epsilon^{U}}^{2}}\left(\sigma_{\epsilon^{U}}^{2}=\bar{\sigma}_{\epsilon}^{2}\right) \text { if: } \\
{\left[\alpha\left(1+\bar{\sigma}_{\epsilon}^{2}\right)+\bar{\sigma}_{\epsilon}^{2}\right]\left[2 I-\alpha\left(1+\bar{\sigma}_{\epsilon}^{2}\right)-\bar{\sigma}_{\epsilon}^{2}\right]+I^{2}\left[1+2 I(I+2)+2(1+I)^{2}(\beta+2) \beta\right]>0 .}
\end{gathered}
$$

This condition holds for a sufficiently high degree of central bank conservatism, $I$.

The intuition for this result is simple. As in the enlarged MU the governments internalise the central bank's reaction to their fiscal decisions to a lesser extent, the disciplining effect of monetary uncertainty has a lower impact on taxes. Thus, the beneficial effect of uncertainty on tax policy is reduced under a common monetary authority.

This result allows us to briefly touch on the issue of optimal degree of preference uncertainty, even though this normative issue is beyond the scope of our paper. When choosing its degree of transparency, the central bank faces a trade-off between the macroeconomic volatility and the fiscal disciplining effect generated by monetary uncertainty. Since the MU enlargement mitigates the latter effect, it renders uncertainty less efficient in improving economic performances on average. As a consequence, the central bank may be induced to be more transparent so as to attenuate macroeconomic instability. 
Now that we have determined the economic outcomes in the enlarged monetary union, we can compare them with those observed in the closed economy and derive the effects of the MU enlargement. These effects are directly related to result 3 .

Formally, to study the impact of the MU enlargement on macroeconomic performances, we first determine its impact on taxes. This is done by considering the difference $\left(\tau_{i}^{U}-\tau_{i}\right), \forall i=1,2$. Once this difference is known, it is straightforward to derive the effects of the MU enlargement on the member countries' average levels of output, inflation and on their public expenditures.

By comparing expression (14) with the equilibrium tax rate observed before the MU enlargement (6), we obtain the following results.

Result 4. Under the assumption of symmetric countries, the MU enlargement increases taxes, average inflation, output distortions and public expenditures when uncertainty is high.

Proof. The comparison of Eq. (6) with Eq. (14) reveals that the MU enlargement has a positive impact on taxes and thus on average inflation, output distortions and public expenditures - as they are positively related to taxes - if the following condition holds:

$$
\sigma_{\epsilon^{U}}^{2}>\frac{I-\alpha}{1+\alpha}
$$

This result extends that obtained by Beetsma and Bovenberg (1998), who emphazised a tax-decreasing effect of (the enlargement of) the monetary union. In our model this occurs for sufficiently low values of monetary uncertainty, $\sigma_{\epsilon^{U}}^{2}$, but a positive impact of the monetary union enlargement on taxes arises when the central bank's opacity about its preferences $\left(\sigma_{\epsilon^{U}}^{2}\right)$ is high. ${ }^{13}$

To understand the intuition underlying result 4 we must note that the overall impact of the monetary union enlargement on fiscal policies (and thereby on economic outcomes) is the consequence of two opposite mechanisms. The first has already been highlighted by Beetsma and Bovenberg (1998). It hinges on the fact that with the monetary union enlargement, the governments' fiscal choices have a smaller impact on monetary policy. More precisely, in the enlarged monetary union, tax increases result in lower average inflation. ${ }^{14}$ Therefore, they are more costly in terms of reduced output, inducing governments to adopt a less aggressive fiscal stance. Hence, through this channel the monetary union enlargement is associated with a diminution in average inflation, output distortions and public expenditures.

\footnotetext{
${ }^{13}$ Note that since the MU extension does not create any additional monetary uncertainty in the participating countries $\left(\sigma_{i}^{2}=\sigma_{\epsilon^{U}}^{2}, \forall i=1,2\right)$, higher inflation and output variability observed in the enlarged MU can only be due to an increase in taxation.

${ }^{14}$ Indeed, from Eqs. (5) and (12) we observe that $\frac{\partial \pi^{U}}{\partial \tau_{i}}<\frac{\partial \pi_{i}}{\partial \tau_{i}}, \forall i=1,2$.
} 
However, in taking into account the fact that the central bank may not be fully transparent, our analysis uncovers a new channel through which the monetary union extension leads to less disciplined fiscal policies. In the larger monetary union, governments internalise the monetary uncertainty created by their tax increases in a lesser extent. Thereby, as demonstrated in the result 3 , the monetary union extension mitigates the 'disciplining effect' that uncertainty has on fiscal decisions and hence encourages higher taxation. The strength of this mechanism is calibrated by the degree of monetary uncertainty, $\sigma_{\epsilon}^{2}$. In particular, when $\sigma_{\epsilon^{U}}^{2}$ is high, this mechanism may dominate the one highlighted by Beetsma and Bovenberg (1998). In this case, the monetary union extension finally results in an increase in taxes, average inflation, output distortions and public expenditures.

If we take the analysis one step further, result 4 also suggests that fiscal coordination may become desirable in a monetary union with relatively low central bank transparency. Indeed, with symmetric countries fiscal coordination yields the same policy outcomes as under the case of a closed economy. It would thus allow to recover fiscal discipline.

From condition (17), we can also easily derive the following result.

Result 5. The lower the central bank's aversion to inflation, I, and/or the higher the relative weight that governments attribute to their inflation objective, $\alpha$, the more the monetary union expansion is likely to increase taxes, average inflation, output distortions and public expenditures.

Proof. See condition (17).

As explained above, through the first mechanism, the monetary union enlargement diminishes the inflationary impact of tax increases and thereby amplifies their cost in terms of reduced output. This, in turn, encourages governments to greater fiscal discipline. However, when the central bank is strongly populist ( $I$ small) and/or the governments slightly concerned about output (relative to inflation - i.e. $\alpha$ large), this mechanism is weakened. Consequently, the second mechanism due to uncertainty is more likely to prevail, implying that the monetary union enlargement may translate into less fiscal moderation.

\subsection{The asymmetric case}

We now turn to the asymmetric case, where we allow for cross-country differences in the targeted level of public expenditures as well as in the relative economic and political weights. ${ }^{15}$ These latter differences capture the idea that smaller countries may have a political weight above their economic weight (Ullrich 2004; Berger 2006). Moreover, we allow for different de-

\footnotetext{
${ }^{15}$ More formally, this implies: $\tilde{g}_{1} \neq \tilde{g}_{2}, s_{1} \neq s_{2}, z_{1} \neq z_{2}$.
} 
grees of uncertainty in the member countries. In particular, we assume that $\sigma_{2}^{2}>\sigma_{1}^{2}$. Hence, even if on average new members have similar preferences to older members $\left(I_{2}=I_{1}=I\right)$, there might be greater variance around the expected value of their preferences. As a consequence, the entry of new members into the MU increases uncertainty in the current member countries (for all $z_{2}>0$ ). This presumption seems realistic at least for an initial period where the public and, in particular, the current members' government need some time to assess the preferences of the larger central bank. ${ }^{16}$ Furthermore, in this case, it is obvious that the additional uncertainty created by the newcomers positively depends on their voting power in the CCB's council (represented by $z_{2}$ ).

However, the assumption that $\sigma_{2}^{2}>\sigma_{1}^{2}$ at the same time implies that the MU extension will reduce uncertainty in the new member countries. This idea could be justified by the fact that, during a transitional period, the candidates for an entry into the MU experience some extra uncertainty due to their adjustment to the new monetary regime which is resolved upon entry. Another interpretation would be that the well established central bank of the MU - for instance, the ECB - may be more predictable than the entering members' national central bank with, for instance, frequently changing governors.

Considering these asymmetries, we can study how the characteristics of the new entering countries may affect the economic outcomes in the current members of the MU and vice versa. Our observations are summarised as follows.

Result 6. An increase in the public expenditures target in country $j$ reduces the tax rate and output distortions in country $i$. The strength of this spillover-effect is increasing in uncertainty $\sigma_{\epsilon^{U}}^{2}$.

Proof. From differentiating (13) with respect to $\tilde{g}_{j}$, we obtain: $\frac{\partial \tau_{i}^{U}}{\partial \tilde{g}_{j}}<0$. Moreover, we also find:

$$
\frac{\partial^{2} \tau_{i}^{U}}{\partial \sigma_{\epsilon^{U}}^{2} \partial \tilde{g}_{j}}=\frac{-s_{i} s_{j} I(\alpha+1) \phi_{i} \phi_{j}}{\left\{\phi_{i} \theta_{j}+s_{i}^{2} \phi_{j}\left[\alpha\left(1+\sigma_{\epsilon^{U}}^{2}\right)+\sigma_{\epsilon^{U}}^{2}\right]\right\}^{2}}<0
$$

The key idea is that an increase in the targeted level of public expenditures in country $j$ not only augments the expected value and the variability of common inflation but it also accrues the variability of output in country $i$. These effects lead the government in country $i$ to reduce its tax rate. ${ }^{17}$

\footnotetext{
${ }^{16}$ This also happened to the initial group of countries forming the European Monetary Union (EMU). As shown by Goldberg and Klein (2005), the perception of the ECB's reaction parameter has changed over time suggesting that the markets refined their view of the ECB's characteristics and objectives.

${ }^{17}$ Note that even if governments are not concerned about price stability $(\alpha=0)$, the
} 
Furthermore, since uncertainty exacerbates the inflation variability created by an increase in country $j$ 's public expenditures target, the strength of the tax decreasing response in country $i$ positively depends on $\sigma_{\epsilon^{U}}^{2}$.

Result 7. An increase in the uncertainty about the monetary preferences in country $j$ reduces the tax rate and output distortions in country $i$. The higher is country j's political weight, the stronger is this effect.

Proof. This result is demonstrated by differentiating $\tau_{i}^{U}$ with respect to $\sigma_{j}^{2}$. We obtain:

$$
\begin{aligned}
\frac{\partial \tau_{i}^{U}}{\partial \sigma_{j}^{2}} & =\frac{\partial \tau_{i}^{U}}{\partial \sigma_{\epsilon^{U}}^{2}} \cdot \frac{\partial \sigma_{\epsilon^{U}}^{2}}{\partial \sigma_{j}^{2}} \\
& =\frac{-z_{j} s_{i} \beta \phi_{j}(1+I)(\alpha+1)\left(s_{i} \tilde{g}_{i} \phi_{j}+s_{j} \tilde{g}_{j} \phi_{i}\right)}{\left\{\phi_{i} \theta_{j}+s_{i}^{2} \phi_{j}\left[\alpha\left(1+\sigma_{\epsilon^{U}}^{2}\right)+\sigma_{\epsilon^{U}}^{2}\right]\right\}^{2}}<0
\end{aligned}
$$

Moreover, as can be seen from this expression, the derivative of $\tau_{i}^{U}$ with respect to $\sigma_{j}^{2}$ is decreasing in the political weight of country $j, z_{j}$.

Greater uncertainty about the monetary preferences in country $j$ augments the uncertainty in the whole MU and thereby favours fiscal discipline in country $i$ as well. Furthermore, as the uncertainty created in the MU by an increase in $\sigma_{j}^{2}$ positively depends on country $j$ 's voting power, so does the strength of the disciplinary effect of $\sigma_{j}^{2}$ on $\tau_{i}^{U}$.

As for the symmetric case, we derive the effects of the monetary union enlargement on macroeconomic performances. Here, we can study how these effects vary across the current and new member countries, depending on their public expenditures target, their economic and political weights as well as on their degree of monetary uncertainty.

Comparison of the tax rate (13) with that observed in country $i$ before the MU extension leads to the following results.

Result 8. Country $i$ may experience an increase in taxes and output distortions due to $M U$ enlargement if its new partner is characterized by lower monetary uncertainty.

Proof. For country $i$, the difference $\left(\tau_{i}^{U}-\tau_{i}\right)$ (where superscript $U$ refers to the situation after the MU extension) is positive if the following condition

public expenditures target in country $j$ would exert downward pressures on the tax rate in country $i$. This is due to the fact that an increase in $\tilde{g}_{j}$ creates monetary uncertainty and thereby raises output variability in country $i$. To counteract this effect, the government in this country reduces taxes. 
holds:

$$
\begin{aligned}
& -\tilde{g}_{i} I s_{j}\left\{\alpha \phi_{i} s_{j}+\phi_{j}\left[I-\alpha\left(1+s_{i}\right)\right]\right\} \\
& +\tilde{g}_{i} I(1+\alpha)\left\{\sigma_{i}^{2} \phi_{j}-\sigma_{\epsilon^{U}}^{2}\left[\phi_{i} s_{j}^{2}+\phi_{j} s_{i}^{2}\right]\right\} \\
& +s_{j}\left(\tilde{g}_{i} s_{j}-\tilde{g}_{j} s_{i}\right)\left[\alpha+(1+\alpha) \sigma_{\epsilon^{U}}^{2}\right]\left[\alpha\left(1+\sigma_{i}^{2}\right)+\sigma_{i}^{2}+I^{2}+I(1+I) \beta\right]>0
\end{aligned}
$$

Let us remind that the degree of uncertainty in the MU is defined by $\sigma_{\epsilon^{U}}^{2}=z_{1} \sigma_{1}^{2}+z_{2} \sigma_{2}^{2}$. Thus, from the second line of condition (18), it appears that the condition under which the MU enlargement leads to higher taxes is more likely to hold when the difference $\left(\sigma_{i}^{2}-\sigma_{\epsilon^{U}}^{2}\right)$ is large.

Hence, since we assumed that the new members in the MU are characterized by higher monetary uncertainty than the older members, result 8 suggests that they may experience a deterioration of their fiscal discipline and thereby see their output distortions increase.

This result can be explained as follows. In the simple case without monetary uncertainty and asymmetries, the MU (enlargement) favours fiscal discipline as in Beetsma and Bovenberg (1998), provided the central bank is sufficiently more inflation averse than the governments (i.e. $I>\alpha$ ). ${ }^{18}$ This result however may be reversed if the assumptions of perfect central bank transparency and symmetric countries are given up.

Indeed, it is possible to show that the countries characterized by a relatively higher degree of monetary uncertainty may experience a further deterioration of fiscal discipline. The intuition is straightforward. For these countries, the larger central bank runs a less uncertain monetary policy than the national central bank did and this induces their governments to raise taxation.

This negative consequence for the new members of the larger MU, however, might be avoided by deliberately creating higher uncertainty in the MU. This could be achieved by increasing their political weight in the larger central bank council because increasing $z_{2}$ lowers the difference between $\sigma_{2}^{2}$ and $\sigma_{\epsilon^{U}}^{2}$.

Result 9. Country $i$ may experience an increase in taxes and output distortions due to the $M U$ enlargement if its new partner has a relatively lower public spending target.

Proof. It is easy to see from the third line of condition (18) that the greater is the difference $\left(\tilde{g}_{i}-\tilde{g}_{j}\right)$, the more the MU enlargement is likely to increase taxes in country $i$.

\footnotetext{
${ }^{18}$ This disciplining effect of the MU extension corresponds to the first term in condition (18).
} 
This result also suggests that monetary unions formed by countries with asymmetric public spending targets are likely to see a further polarization of their national fiscal policies.

Indeed, for the countries with a high public spending target, the MU extension implies that the central bank will no longer react as strongly as it did due to the fiscal moderation of their new partners. Hence, inflationary pressure (on average and in terms of variance) automatically declines, encouraging the government in these countries to adopt a more aggressive fiscal stance.

Moreover, as can be seen from condition (18), the strength of this effect positively depends on the degree of uncertainty in the enlarged MU. The higher is $\sigma_{\epsilon^{U}}^{2}$, the greater is the governments' perception of the decline in inflation variability due to the fiscal discipline of their new partners.

Thus, increased uncertainty with the MU enlargement does not necessarily prove to be beneficial for countries with a high public spending target. This observation somewhat qualifies our preceding results about the desirability of less central bank transparency in the MU.

\section{Conclusion}

This paper has demonstrated that uncertainty about the monetary authorities relative preferences for output and inflation stabilization has a systematic influence on the optimal fiscal policies of governments. In particular, we found, in line with the literature, that uncertainty can discipline policy makers, thereby leading to lower taxes, average inflation and output distortions. We extended this well known result by introducing the case of a monetary union and allowing for asymmetries between member countries. The larger a monetary union would be, the less governments would internalize the disciplinary effect of uncertainty and thus pursue a more aggressive tax policy. In the case of symmetric countries, it would thereby be an appropriate response by the central bank to become less transparent in a larger union.

By looking at asymmetries, we found that monetary union and the move to a larger central bank may increase uncertainty for some countries but lower it for others, depending on the behaviour of the national central bank in comparison to what the common central bank does. Given this asymmetric influence of monetary union on the degree of uncertainty in different member states, we could expect an increase of taxation (and thus lower output distortions) in those countries where uncertainty is reduced. We thus have a convergence in levels of taxation. Those countries where uncertainty is reduced increase taxation and vice versa. Applied to the European integration process, this would mean that taxation in new member states would increase while it would fall in older member states. This should have positive effects in older states and negative one in the new states. To counter this negative 
influence an increase in the political weight of the countries characterized by a high degree of uncertainty might be beneficial.

We do not argue, however, that such an increase in uncertainty is a systematically efficient response to the potential tax-increasing effects of a larger MU. Indeed, by considering cross-country asymmetries in the governments' objectives, we show that the MU enlargement may lead to higher taxation in countries with a relatively high spending target as they take advantage of their partners' fiscal discipline. Higher uncertainty in the MU then even strengthens this effect.

Finally, our analysis does not provide any clear-cut argument to the debate about the desirability of central bank transparency. On the contrary, it underlines the crucial implications of asymmetric fiscal policies in the MU for the appropriate choice of central bank transparency. 


\section{References}

Beetsma R, Bovenberg A (1997) Designing fiscal and monetary institutions in a second best world. Eur J Polit Econ 13: 53-79

Beetsma R, Bovenberg A (1998) Monetary union without fiscal coordination may discipline policymakers. J Int Econ 45: 239-258

Beetsma R, Bovenberg A (1999) Does monetary unification lead to excessive debt accumulation? J Public Econ 74: 299-325

Beetsma R, Uhlig H (1999) An analysis of the Stability and Growth Pact. Econ J 109: 546-571

Benigno P (2004) Optimal monetary policy in a currency area. J Int Econ 63: 293-320

Berger H (2006) Optimal central bank design: Benchmarks from the ECB. Rev Int Organ 1: 207-235

Blinder A (1998) Central banking in theory and practice. MIT Press, Cambridge

Blinder A, Goodhart C, Hildebrand P, Lipton D, Wyplosz C (2001) How do central banks talk? Geneva Reports on the World Economy 3

Brainard W (1967) Uncertainty and the effectiveness of policy. Am Econ Rev 57: 411-425

Ciccarone C, Di Bartolomeo G, Marchetti E (2007) Unions, fiscal policy and central bank transparency. Manch Sch 75: 617-633

Cukierman A, Lippi F (1999) Central bank independence, centralization of wage bargaining, inflation and unemployment: Theory and evidence. Eur Econ Rev 43: 1395-1434

Cukierman A, Meltzer A (1986) A theory of ambiguity, credibility and independence under discretion and asymmetric information. Econometrica 54: $1099-1128$

Demertzis M, Hughes Hallett A (2007) Central bank transparency in theory and practice. J Macroecon 29: 760-789

Dincer N, Eichengreen B (2007) Central bank transparency: where, why and with what effects? NBER Working Paper 13003

Dixit A, Lambertini L (2001) Monetary-fiscal policy interactions and commitment versus discretion in a monetary union. Eur Econ Rev 45: 977-987

Dixit A, Lambertini L (2003) Symbiosis of monetary and fiscal policies in a monetary union. J Int Econ 60: 235-247

Drazen A, Brender A (2005) Political budget cycles in new versus established democracies. J Monet Econ 52: 1271-1295

Eijffinger S, Hoeberichts M (2000) Central bank accountability and transparency: Theory and some evidence. Bundesbank Discussion Paper 06/11

Eijffinger S, van der Cruijsen C (2007) The economic impact of central bank transparency: A survey. CEPR Discussion Papers 6070

Geraats P (2002) Central bank transparency. Econ J 112: 532-565 
Goldberg L, Klein M (2005) Establishing credibility: Evolving perceptions of the European Central Bank. NEBR Working Paper 11792

Grüner H P (2002) How much should central banks talk? A new argument. Econ Lett 77: 195-198

Grüner H P, Hayo B, Hefeker C (2005) Unions, wage setting and monetary policy uncertainty. ECB Working Paper Series 490

Gros D, Hefeker C (2002) One size must fit all. National divergences in a monetary union. Ger Econ Rev 3: 242-267

Hughes Hallett A, Libich J (2006) Central bank independence, accountability and transparency: Complements or strategic substitutes? CEPR Discussion Paper 5470

Hughes Hallett A, Viegi N (2003) Transparency and the strategic use of private information in monetary policy. Manch Sch 71: 498-520

Söderström U (2002) Monetary policy with uncertain parameters. Scand J Econ 104: 125-145

Sorensen J (1991) Political uncertainty and macroeconomic performance. Econ Lett 37

Uhlig H (2003) One money but many fiscal policies in Europe: What are the consequences? In: Buti M (ed) Monetary and fiscal policies in EMU. Cambridge University Press, Cambridge, pp 29-56

Ullrich K (2004) Decision making in the ECB: Reform and voting power. ZEW Discussion Paper 04-70

von Hagen J, Wyplosz C. (2008) EMU's decentralized system of fiscal policy, European Economy Economic Papers 306.

Winkler B (2000) Which kind of transparency: On the need for clarity in monetary policy making, ECB Working Paper 26. 


\section{CESifo Working Paper Series}

for full list see www.cesifo-group.org/wp

(address: Poschingerstr. 5, 81679 Munich, Germany, office@cesifo.de)

2325 Helmuth Cremer, Philippe De Donder, Dario Maldonado and Pierre Pestieau, Forced Saving, Redistribution and Nonlinear Social Security Schemes, June 2008

2326 M. Hashem Pesaran and Paolo Zaffaroni, Optimal Asset Allocation with Factor Models for Large Portfolios, June 2008

2327 Harald Badinger and Peter Egger, Horizontal versus Vertical Interdependence in Multinational Activity, June 2008

2328 Jan K. Brueckner and Harris Selod, A Theory of Urban Squatting and Land-Tenure Formalization in Developing Countries, June 2008

2329 Paolo M. Panteghini, Corporate Debt, Hybrid Securities and the Effective Tax Rate, June 2008

2330 Guglielmo Maria Caporale, Juncal Cuñado and Luis A. Gil-Alana, Modelling Long-Run Trends and Cycles in Financial Time Series Data, June 2008

2331 Avi Ben-Bassat and Momi Dahan, Social Identity and Voter Turnout, June 2008

2332 Martin R. West and Ludger Wößmann, "Every Catholic Child in a Catholic School”: Historical Resistance to State Schooling, Contemporary Private Competition, and Student Achievement across Countries, June 2008

2333 Erkki Koskela and Panu Poutvaara, Outsourcing and Labor Taxation in Dual Labor Markets, June 2008

2334 Philippe Choné and Laurent Linnemer, Optimal Litigation Strategies with Signaling and Screening, June 2008

2335 Albert Solé-Ollé and Pilar Sorribas-Navarro, Does Partisan Alignment Affect the Electoral Reward of Intergovernmental Transfers?, June 2008

2336 Antonio Cabrales and Piero Gottardi, Markets for Information: Of Inefficient Firewalls and Efficient Monopolies, June 2008

2337 Sumon Majumdar and Sharun W. Mukand, The Leader as Catalyst - on Leadership and the Mechanics of Institutional Change, June 2008

2338 Ulrich Hange, Tax Competition, Elastic Labor Supply, and Growth, June 2008

2339 Guy Laroque and Bernard Salanié, Does Fertility Respond to Financial Incentives?, June 2008 
2340 Adriano Paggiaro, Enrico Rettore and Ugo Trivellato, The Effect of Extending the Duration of Eligibility in an Italian Labour Market Programme for Dismissed Workers, June 2008

2341 Helmut Seitz, Minimum Standards, Fixed Costs and Taxing Autonomy of Subnational Governments, June 2008

2342 Robert S. Chirinko, Leo de Haan and Elmer Sterken, Asset Price Shocks, Real Expenditures, and Financial Structure: A Multi-Country Analysis, July 2008

2343 Wolfgang Leininger, Evolutionarily Stable Preferences in Contests, July 2008

2344 Hartmut Egger and Udo Kreickemeier, Fairness, Trade, and Inequality, July 2008

2345 Ngo Van Long and Bodhisattva Sengupta, Yardstick Competition, Corruption, and Electoral Incentives, July 2008

2346 Florian Baumann, Employment Protection: The Case of Limited Enforceability, July 2008

2347 Alessandro Balestrino, Cinzia Ciardi and Claudio Mammini, On the Causes and Consequences of Divorce, July 2008

2348 Dirk Schindler and Benjamin Weigert, Insuring Educational Risk: Opportunities versus Income, July 2008

2349 Lammertjan Dam and Ben J. Heijdra, The Environmental and Macroeconomic Effects of Socially Responsible Investment, July 2008

2350 Avner Greif, Contract Enforcement and Institutions among the Maghribi Traders: Refuting Edwards and Ogilvie, July 2008

2351 Helmuth Cremer, Philippe De Donder, Dario Maldonado and Pierre Pestieau, Habit Formation and Labor Supply, July 2008

2352 Francesco Menoncin and Paolo M. Panteghini, The Johansson-Samuelson Theorem in General Equilibrium: A Rebuttal, July 2008

2353 Michael Kaganovich and Itzhak Zilcha, Alternative Social Security Systems and Growth, July 2008

2354 Keith Blackburn, Kyriakos C. Neanidis and M. Emranul Haque, Corruption, Seigniorage and Growth: Theory and Evidence, July 2008

2355 Edward Castronova, A Test of the Law of Demand in a Virtual World: Exploring the Petri Dish Approach to Social Science, July 2008

2356 Harald Badinger and Peter Egger, GM Estimation of Higher-Order Spatial Autoregressive Processes in Cross-Section Models with Heteroskedastic Disturbances, July 2008 
2357 Wolfgang Buchholz and Jan Schumacher, Discounting the Long-Distant Future: A Simple Explanation for the Weitzman-Gollier-Puzzle, July 2008

2358 Luca Anderlini, Leonardo Felli and Alessandro Riboni, Statute Law or Case Law?, July 2008

2359 Guglielmo Maria Caporale, Davide Ciferri and Alessandro Girardi, Are the Baltic Countries Ready to Adopt the Euro? A Generalised Purchasing Power Parity Approach, July 2008

2360 Erkki Koskela and Ronnie Schöb, Outsourcing of Unionized Firms and the Impacts of Labour Market Policy Reforms, July 2008

2361 Francisco Alvarez-Cuadrado and Ngo Van Long, A Permanent Income Version of the Relative Income Hypothesis, July 2008

2362 Gabrielle Demange, Robert Fenge and Silke Uebelmesser, Financing Higher Education and Labor Mobility, July 2008

2363 Alessandra Casarico and Alessandro Sommacal, Labor Income Taxation, Human Capital and Growth: The Role of Child Care, August 2008

2364 Antonis Adam, Manthos D. Delis and Pantelis Kammas, Fiscal Decentralization and Public Sector Efficiency: Evidence from OECD Countries, August 2008

2365 Stefan Voigt, The (Economic) Effects of Lay Participation in Courts - A Cross-Country Analysis, August 2008

2366 Tobias König and Andreas Wagener, (Post-)Materialist Attitudes and the Mix of Capital and Labour Taxation, August 2008

2367 Ximing Wu, Andreas Savvides and Thanasis Stengos, The Global Joint Distribution of Income and Health, August 2008

2368 Alejandro Donado and Klaus Wälde, Trade Unions Go Global!, August 2008

2369 Hans Gersbach and Hans Haller, Exit and Power in General Equilibrium, August 2008

2370 Jan P.A.M. Jacobs and Jan-Egbert Sturm, The Information Content of KOF Indicators on Swiss Current Account Data Revisions, August 2008

2371 Oliver Hülsewig, Johannes Mayr and Timo Wollmershäuser, Forecasting Euro Area Real GDP: Optimal Pooling of Information, August 2008

2372 Tigran Poghosyan and Jakob de Haan, Determinants of Cross-Border Bank Acquisitions in Transition Economies: A Latent Class Analysis, August 2008

2373 David Anthoff and Richard S.J. Tol, On International Equity Weights and National Decision Making on Climate Change, August 2008 
2374 Florian Englmaier and Arno Schmöller, Reserve Price Formation in Online Auctions, August 2008

2375 Karl Farmer, Birgit Friedl and Andreas Rainer, Effects of Unilateral Climate Policy on Terms of Trade, Capital Accumulation, and Welfare in a World Economy, August 2008

2376 Monika Bütler, Stefan Staubli and Maria Grazia Zito, The Role of the Annuity’s Value on the Decision (Not) to Annuitize: Evidence from a Large Policy Change, August 2008

2377 Inmaculada Martínez-Zarzoso, The Impact of Urbanization on $\mathrm{CO}_{2}$ Emissions: Evidence from Developing Countries, August 2008

2378 Brian Roberson and Dmitriy Kvasov, The Non-Constant-Sum Colonel Blotto Game, August 2008

2379 Ian Dew-Becker, How Much Sunlight Does it Take to Disinfect a Boardroom? A Short History of Executive Compensation Regulation, August 2008

2380 Cécile Aubert, Oliver Falck and Stephan Heblich, Subsidizing National Champions: An Evolutionary Perspective, August 2008

2381 Sebastian Buhai, Miguel Portela, Coen Teulings and Aico van Vuuren, Returns to Tenure or Seniority?, August 2008

2382 Erkki Koskela and Jan König, Flexible Outsourcing, Profit Sharing and Equilibrium Unemployment, August 2008

2383 Torberg Falch and Justina AV Fischer, Does a Generous Welfare State Crowd out Student Achievement? Panel Data Evidence from International Student Tests, September 2008

2384 Pedro Gomes and François Pouget, Corporate Tax Competition and the Decline of Public Investment, September 2008

2385 Marko Koethenbuerger, How Do Local Governments Decide on Public Policy in Fiscal Federalism? Tax vs. Expenditure Optimization, September 2008

2386 Ronald McKinnon and Gunther Schnabl, China’s Exchange Rate Impasse and the Weak U.S. Dollar, September 2008

2387 Yan-Leung Cheung, Yin-Wong Cheung and Alan T.K. Wan, A High-Low Model of Daily Stock Price Ranges, September 2008

2388 Louis Eeckhoudt and Harris Schlesinger, Changes in Risk and the Demand for Saving, September 2008

2389 Carsten Hefeker and Blandine Zimmer, Uncertainty and Fiscal Policy in an Asymmetric Monetary Union, September 2008 